\title{
PEMANFAATAN MEDIA MONOPOLI UNTUK MENINGKATKAN KEAKTIFAN DAN HASIL BELAJAR IPA SISWA KELAS III SDN SUGIHWARAS KECAMATAN MAOSPATI KABUPATEN MAGETAN TAHUN PELAJARAN 2015/2016
}

\author{
Anang Gatot Subroto' ${ }^{1)}$, R. Bekti Kiswardianta ${ }^{2)}$, M.S. Djoko Laksana ${ }^{3)}$ \\ ${ }^{1,3)}$ Program Studi PGSD FIP IKIP PGRI Madiun \\ ${ }^{2)}$ Program Studi Pendidikan Biologi FPMIPA IKIP PGRI Madiun \\ Jalan Setiabudi No. 85 Madiun \\ email:poesky86@gmail.com
}

Diterima 15 Juli 2016, Disetujui 07 Oktober 2016

\begin{abstract}
Education is an important role in improving human resources. SDN Sugihwaras 2 Maospati have adequate facilities and infrastructure, but its use is not maximized. Such conditions make the learning in the classroom in which there are still many students spoke with fear, students tend to give silent resulted in low learning outcomes. Implementation of education are encouraged to use effective learning media that give pleasure to support student learning outcomes give liveliness. Based on these problems, researchers conduct studies in SDN Sugihwaras 2 Maospati. Media monopoly in learning aims to enhance the activity and learning outcomes third grade students in science subjects. The research was conducted in the SDN Sugihwaras 2 Maospati. Data collection techniques were used that observation, documentation, tests, and interviews. Results showed that the average use of monopoly can enhance the activity of learning outcomes. Data were obtained that the learning outcomes of the first cycle completeness $45 \%$ give students who are not on $55 \%$ due to the second cycle increased to $75 \%$ Students who complete $25 \%$ give students conclusion is not. Liveliness to the results of the first cycle $20 \%$ liveliness students are active, $45 \%$ of students are quite active, give $35 \%$ of students are less active. In the second cycle there is an increasing involvement of the student to be $70 \%$ of active students. It can be concluded there is an increase learning outcomes and student activity by monopoly media.
\end{abstract}

Keywords: Monopoly, Motivation, Learning Outcomes, science.

\section{PENDAHULUAN}

SDN Sugihwaras merupakan sekolah dasar yang terletak di Desa Sugihwaras jalan raya Maospati Kecamatan Maospati Kabupaten Magetan. Sekolah dasar ini memiliki fasilitas dan sarana prasarana yang cukup memadai yang dapat digunakan dalam pembelajaran seperti: lapangan voli, basket, futsal, tenis meja, alat peraga, perpustakaan, dan sebagainya. Penggunaan fasilitas maupun sarana dan prasarana belum maksimal. Alat peraga masih minim digunakan dalam proses pembelajaran, sehingga pada saat pembelajaran di kelas fasilitas dan sarana prasarana hanya ditaruh di perpustakaan.
Berdasarkan hasil observasi yang dilakukan peneliti di SDN Sugihwaras ini, peneliti tertarik pada siswa-siswi kelas III. Siswa- siswi ini pada saat proses belajar dikelas terlihat kurang aktif. Dilihat pada saat pembelajaran di kelas saat guru memberikan pertanyaan tentang materi, siswa cenderung diam dan tidak merespon pertanyaan dari guru. Siswa asyik sendiri dengan teman sebangku, bahkan ramai sendiri dan membuat gaduh suasana di kelas.

Siswa kelas III berjumlah 20 anak yang terdiri dari 8 anak laki-laki dan 12 anak perempuan. Pada saat pembelajaran siswa-siswi kelas III lebih senang berbicara dengan teman dari pada mendengarkan 
penjelasan guru. Terkadang siswa ramai dengan berpindah tempat duduk dan membuat suasana kelas tidak kondusif. Selain itu, siswa yang duduk di kelas III pada saat diadakan evaluasi pembelajaran pada mata pelajaran IPA masih banyak siswa yang belum tuntas dari KKM. Dari KKM 70 yang sudah tuntas baru $40 \%$ siswa, sedangkan siswa yang lain belum tuntas. Hasil belajar yang tergolong rendah yang terdapat pada hasil evaluasi pada pembelajaran IPA.

Melihat kondisi seperti ini maka perlu dilakukan perbaikan dalam proses pembelajaran. Hal ini bertujuan untuk meningkatkan keaktifan dan hasil belajar siswa. Salah satu upaya perbaikan pembelajaran dengan menggunakan media yang efektif dan menarik pada saat menyampaikan materi. Pemilihan media yang menarik akan membuat siswa merasa senang, karena anak SD masih suka bermain. Djamarah, (2010) bahwa "media adalah alat bantu apa saja yang dapat dijadikan sebagai penyalur pesan guna mencapai tujuan pengajaran". Salah satu media pembelajaran yang menyenangkan dengan menggunakan permaian media monopoli. Permainan ini disesuaikan dengan kondisi siswa setiap hari yang masih suka bermain. Dengan media monopoli siswa akan mencoba mengalami sendiri proses pembelajaran, sehingga pembelajaran terasa menyenangkan bagi siswa. Melihat dari latar belakang dan kegunaaan media monopoli, penulis akan meneliti tentang "Pemanfaatan Media Monopoli Untuk Meningkatkan Keaktifan dan Hasil Belajar IPA Kelas III SDN Sugihwaras Kecamatan Maospati Kabupaten Magetan Tahun Pelajaran 2015/2016"

Tujuan yang ingin dicapai dalam penelitian ini adalah untuk meningkatkan keaktifan dan hasil belajar siswa di SDN Sigihwaras Kecamatan Maospati Kabupaten Magetan dengan menerapkan media monopoli.

\section{METODE}

Penelitian ini dilakukan di SDN Sugihwaras Kecamatan Maospati Kabupaten Magetan Tahun Pelajaran 2015/2016. Penelitian ini dilaksanakan pada semester genap tahun pelajaran 2015/2016 mulai bulan Maret sampai dengan bulan Juli 2016.

Dalam penelitian ini digunakan beberapa pendekatan dan jenis penelitian untuk mengumpulkan data. Penelitian ini termasuk dalam Penelitian Tindakan Kelas (PTK). Rancangan penelitian tindakan kelas ini dilakukan beberapa siklus. Apabila dalam pelaksanaan tindakan belum memcapai tujuan yang diharapkan, maka dilanjutkan pada siklus berikutnya sampai memperoleh hasil yang diharapkan.

Subjek penelitian adalah seluruh siswa kelas III SDN Sugihwaras Kecamatan Maospati Kabupaten Magetan Tahun Pelajaran 2015/2016. Berdasarkan hasil observasi di SDN Sugihwaras Kecamatan Maospati Kabupaten Magetan, diketahui bahwa seluruh kelas III yang berjumlah 20 anak, yang terdiri dari 8 anak laki-laki dan 12 anak perempuan. Teknik pengumpulan data yang dilakukan pada penelitian ini adalah metode observasi, wawancara, tes, dan dokementasi.

Penelitian direncanakan sebanyak 2 siklus, akan tetapi tidak menutup kemungkinan dilanjutkan ke siklus selanjutnya apabila belum memenuhi target yang telah ditentukan. Prosedur dan langkah-langkah dalam melaksanakan tindakan penelitian tindakan kelas ini mengacu pada prosedur penelitian tindakan kelas yang diaplikasikan dari model tindakan. Menurut Arikunto, (2014) bahwa secara garis besar terdapat empat tahapan yang lazim dilalui, yaitu (1) perencanaan, (2) pelaksanaan, (3) pengamatan, (4) refleksi. Peneliti membagi jadwal penelitian dalam 4 tahap yaitu : Tahap 1 . Rancangan Tindakan, Tahap 2. Pelaksanaan Tindakan, Tahap 3. Pengamatan Tindakan, dan Tahap 4. Refleksi Tindakan. 
Teknik yang digunakan dalam mengolah dan menganalisis data dilakukan dengan analisis kualitatif dan analisis kuantitatif. Analisis data kualitatif digunakan untuk menganalisis data yang diperoleh dari observasi, wawancara, dan dokumentasi. Teknik kualitatif digunakan untuk menentukan peningkatan proses belajar khususnya tindakan yang dilakukan oleh peneliti, sedangkan data kuantitatif digunakan untuk menentukan peningkatan hasil belajar siswa sebagai pengaruh dari setiap tindakan yang dilakukan oleh guru.

1. Data keaktifan siswa

Data keaktifan siswa diambil melalui lembar observasi siswa

Nilai individu $=\frac{\text { skoryangdiperoleh }}{\text { skortertinggi }} \times 100$

Tabel 1. Kriteria penyajian

\begin{tabular}{lll}
$\begin{array}{l}\text { Kategori } \\
\text { Nilai }\end{array}$ & $\begin{array}{c}\text { Rentang } \\
\text { Nilai } \\
\text { Keaktifan }\end{array}$ & Keterangan \\
\hline $0-100$ & $8-20$ & Sangat aktif \\
$0-80$ & $4-17$ & Aktif \\
$0-60$ & $9-13$ & Cukup \\
$0-40$ & $5-8$ & Kurang \\
0 & $0-4$ & Tidak aktif \\
\hline \multicolumn{3}{l}{ Indikator pencapaian keaktifan }
\end{tabular}
siswa, jika nilai yang diperoleh siswa sudah mencapai 70 yaitu kategori aktif. Data keaktifan siswa secara klasikal dihitung dengan rumus:

$$
\text { Prosentase }=\frac{\sum \text { siswayangtwntas }}{\sum \text { seluruhsiswa }} \times 100 \%
$$

Jika indikator pencapaian keaktifan siswa secara klasikal $70 \%$ dari keseluruhan siswa mencapai kategori aktif.

\section{Data hasil belajar siswa}

Penilaian data hasil belajar siswa melalui tes tulis (post test). Nilai siswa secara individu dihitung dengan rumus:
Nilai $=\frac{\text { skoryangdiperoleh }}{\text { skortertinggi }} \times 100$

Indikator keberhasilan siswa secara individu, siswa dikatakan tuntas apabila mencapai nilai 70 .

Ketuntasan belajar secara klasikal dihitung dengan rumus:

Prosentase $=\frac{\sum \text { siswayangtuntas }}{\sum \text { seluruhsiswa }} \times 100 \%$

Pencapaian indikator hasil belajar secara klasikal apabila $70 \%$ dari keseluruhan siswa mencapai ketuntasan belajar.

\section{HASIL DAN PEMBAHASAN}

\section{Siklus 1}

1.Data keaktifan siswa

Data keaktifan siswa diambil dengan cara observasi siswa selama proses pembelajaran berlangsung dengan menggunakan media monopoli. Keseluruhan siswa $20 \%$ siswa sudah aktif atau 4 siswa. Tetapi belum ada siswa yang sangat aktif didalam kelas, selain itu juga terdapat siswa cukup aktif sebesar $45 \%$ dari 9 siswa. Siswa yang kurang aktif sebesar $35 \%$ atau 7 siswa yang kurang aktif. Siswa yang tidak aktif sebesar 0\%.Dengan hasil tersebut masih belum memenuhi indikator pencapaian keaktifan siswa yaitu apabila $\geq 70 \%$ dari keseluruhan siswa aktif. Dengan demikian perlu adanya perbaikan pada siklus berikutnya.

\section{Data Hasil Belajar Siswa}

Data hasil belajar siswa diperoleh dengan cara post test selesai mengikuti pembelajaran dengan menggunakan media monopoli. Data menunjukkan bahwa dari jumlah 20 siswa ada 15 siswa yang sudah mampu mencapai ketuntasan belajar, atau $75 \%$. Sedangkan masih ada 5 siswa yang belum mencapai ketuntasan belajar atau $25 \%$ siswa yang belum tuntas. Sehingga tingkat ketuntasan klasikal $75 \%$. Dengan hasil tersebut sudah memenuhi kriteria ketuntasan klasikal yaitu $\geq 70 \%$. Dengan 
demikian secara klasikal siswa sudah mampu mencapai indikator hasil belajar.

Siklus 2

\section{Data Keaktifan Siswa}

Data keaktifan siswa diambil dengan cara observasi siswa selama proses pembelajaran berlangsung dengan menggunakan media monopoli.

Data menunjukkan bahwa dari keseluruhan siswa 10\% siswa sudah sangat aktif atau 2 siswa sangat aktif. 70\% siswa sudah aktif atau 14 siswa sudah aktif. Selain itu terdapat $20 \%$ siswa yang cukup aktif atau berjumlah 4 orang siswa. Sedangkan untuk siswa yang kurang aktif dan tidak aktif sebanyak0 siswa dengan prosentase $0 \%$. Dengan hasil tersebut sudah mencapai atau memenuhi indikator pencapaian keaktifan siswa yaitu $\geq 70 \%$ siswa aktif. Secara klasikal siswa sudah mencapai indikator keaktifan siswa.

\section{Pembahasan}

\section{Peningkatan Hasil Belajar siswa}

Penguasaan terhadap konsep pada proses pembelajaran dapat meningkatkan hasil belajar siswa. Namun hasil belajar dalam pelaksanaan penelitian memperlihatkan bahwa siswa yang sangat aktif belum tentu memperlihatkan hasil belajar yang baik pula, hal ini dapat dilihat dari hasil yang di dapat dari siklus 1 dan siklus 2.Hasil belajar siswa dapat dilihat pada penilaian evaluasi siswa. Pada siklus II dikatakan berhasil bahwa hasil belajar siswa meningkat dibandingkan siklus I.Peningkatan tersebut dapat dilihat pada tabel 2. berikut :

\begin{tabular}{|c|c|c|c|c|c|}
\hline \multirow[b]{2}{*}{$\begin{array}{l}\text { Indi- } \\
\text { kater } \\
\text { ketun- } \\
\text { tasan }\end{array}$} & \multirow[b]{2}{*}{$\begin{array}{l}\text { Kri- } \\
\text { teria }\end{array}$} & \multicolumn{2}{|c|}{ Sikles I } & \multicolumn{2}{|c|}{ Siklus II } \\
\hline & & $\begin{array}{c}\text { Freka } \\
\text { resil }\end{array}$ & $\begin{array}{l}\text { Pro- } \\
\text { seatase } \\
(\%)\end{array}$ & $\begin{array}{l}\text { Freka } \\
\text { easi }\end{array}$ & $\begin{array}{l}\text { Prosen } \\
\text { tase } \\
(\%)\end{array}$ \\
\hline $0 \%$ & Tuntas & 9 & 5 & 5 & 5 \\
\hline $0 \%$ & $\begin{array}{l}\text { Tidak } \\
\text { Tuntas }\end{array}$ & 1 & 5 & 5 & 5 \\
\hline \multicolumn{2}{|l|}{ Jumlah } & 10 & 10 & 10 & 10 \\
\hline
\end{tabular}

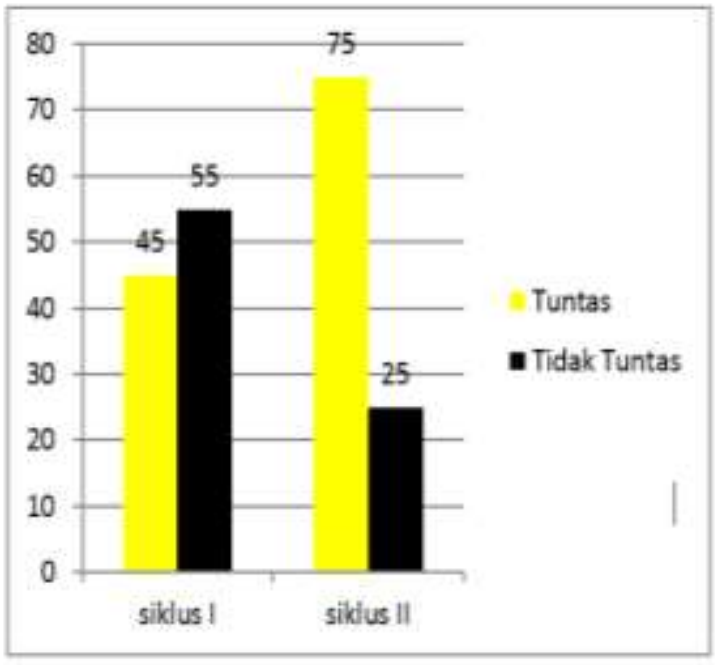

Gambar 1. Peningkatan Hasil Belajar Pada Siklus I dan Siklus II

Gambar 1 menunjukkan bahwa perbandingan siswa yang tuntas belajar dengan siswa yang belum tuntas berbanding terbalik antara pembelajaran siklus I, dan siklus II. Data tersebut menunjukkan bahwa hasil belajar siswa mengalami peningkatan. Ketuntasan belajar secara klasikal pada pembelajaran siklus I dan siklus II mengalami peningkatan yaitu $45 \%$ dan $75 \%$ sedangkan ketidaktuntasan atau belum tuntas belajar secara klasikal menurun yaitu $55 \%$ dan $25 \%$.

Daryanto (2010) menyatakan bahwa media merupakan salah satu komponen komunikasi, yaitu sebagai pembawa pesan dari komunikator menuju komunikan. Sedangkan Hamalik (dalam Arsyad 2011) menyatakan bahwa pemakaian media pembelajaran dalam proses belajar mengajar dapat membangkitkan keinginan dan minat baru, membangkitkan motivasi dan rangsangan kegiatan belajar dan bahkan membawa pengaruh-pengaruh psikologi dalam siswa.

\section{Peningkatan Keaktifan Siswa}

Proses pembelajaran pada siklus I sudah mengalami peningkatan dibandingkan dengan pembelajaran awal. Pada pembelajaran awal keaktifan siswa belum muncul. Hal ini disebabkan penggunaan media yang belum maksimal 
dan letak sekolah yang berada di dekat jalan raya.Peningkatan keaktifan siswa dalam pembelajaran siklus I mengalami peningkatan namun belum optimal sehingga peneliti dan guru melanjutkan dalam siklus

Tabel 3. Peningkatan keaktifan siswa siklus I dan siklus II

\begin{tabular}{lcccc}
\hline \multirow{2}{*}{ Kriteria } & \multicolumn{2}{c}{ Siklus I } & \multicolumn{2}{c}{ Siklus II } \\
\cline { 2 - 5 } & Frekuensi & Presentase \% & Frekuensi & Presentase \% \\
\hline Siswa Sangat Aktif & - & - & 2 & 10 \\
Siswa Aktif & 4 & 20 & 14 & 70 \\
Siswa Cukup Aktif & 9 & 45 & 4 & 20 \\
Siswa Kurang Aktif & 7 & 35 & - & - \\
Siswa Tidak Aktif & - & - & - & - \\
\multicolumn{1}{c}{ Jumlah } & $\mathbf{2 0}$ & $\mathbf{1 0 0}$ & $\mathbf{2 0}$ & $\mathbf{1 0 0}$ \\
\hline
\end{tabular}

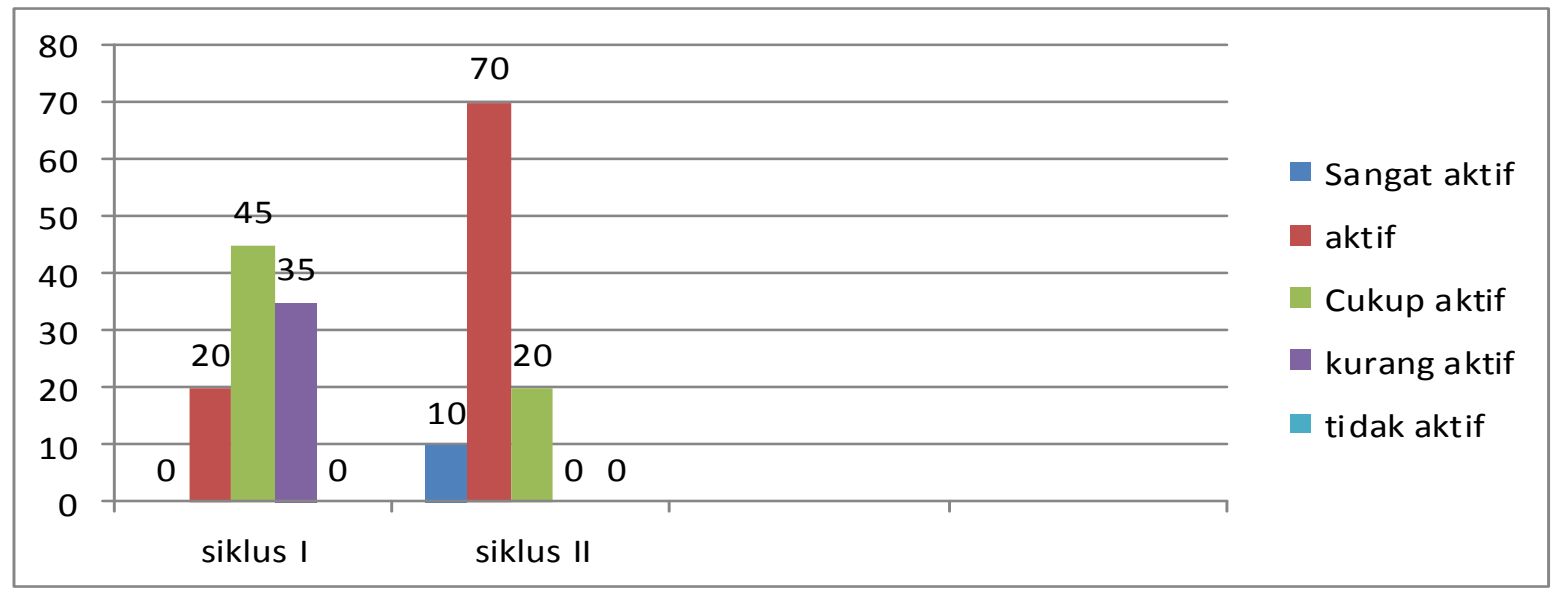

Gambar 2. Grafik peningkatan keaktifan siswa

Dari gambar 2 diatas, maka dapat diperoleh informasi bahwa keaktifan siswa pada siklus II meningkat. Yang semula pada siklus I siswa yang aktif hanya 4 anak atau $20 \%$, pada siklus II siswa yang aktif menjadi 14 atau $70 \%$ anak, bahkan ada siswa yang sangat aktif berjumlah 2 anak atau $10 \%$. Hal ini disebabkan semua siswa berkesempatan memainkan media monopoli.

Pembelajaran yang aktif akan membuat siswa aktif dalam pembelajaran. Marno (dalam Pratiwi 2013) menyatakan bahwa belajar aktif dapat membantu siswa untuk menghidupkan dan melatih memori siswa agar bekerja dan berkembang secara optimal. Sedangkan Nana Sudjana (dalam Pratiwi 2013) menyatakan dalam proses pembelajaran, kegiatan belajar aktif dapat dilihat dari beberapa hal yaitu, turut serta dalam melaksanakan tugas belajarnya, terlibat dalam pemecahan masalah,bertanya kepada siswa lain atau guru apabila tidak memahami persoalan yang dihadapinya, berusaha mencari berbagai informasi yang diperlukan untuk pemecah masalah, melaksanakan diskusi kelompok sesuai dengan petunjuk guru, menilai kemampuan dirinya dari hasil-hasil yang diperolehnya, melatih diri dalam memecahkan soal atau 
masalah yang sejenis.Penggunaan media monopoli yang dilakukan memunculkan keaktifan siswa sebab memunculkan suasana pembelajaran yang menyenangkan bagi siswa seperti penugasan, tanya jawab, serta bimbingan yang sangat berarti dari guru kelas maupun peneliti, sehingga suasana belajar yang tercipta lebih menyenangkan dan bemakna.

Pembahasan diatas menunjukan bahwa dengan pemanfataan media monopoli dapat meningkatan keaktifan dan hasil belajar siswa, sehingga siswa dapat mencapai Kriteria Ketuntasan Minimum (KKM) pada mata pelajaran IPA. Dari hasil penelitian yang dilakukan dapat diketahui bahwa penelitian telah mengalami keberhasilan.

\section{SIMPULAN}

Berdasarkan penelitian tindakan kelas yang telah dilaksanakan pada siswa kelas III SDN Sugihwaras 2 Maospati dapat disimpulkan bahwa penggunaan media monopoli dapat meningkatkan keaktifan dan hasil belajar IPA pada siswa kelas III SDN Sugihwaras 2 Kecamatan Maospati Kabupaten Magetan.

Dari hasil analisis data observasi yang dilaksanakan pada saat pembelajaran dengan pemanfataan media monopoli terdapat peningkatan keaktifan dan hasil belajar siswa dari siklus I dan siklus II.Diketahui pada siklus I keaktifan siswa baru mencapai $20 \%$ atau 4 siswa. pada siklus ke 2 keaktifan belajar mencapai $70 \%$ atau 14 siswa, bahkan ada $10 \%$ atau 2 siswa yang sangat aktif. Ketuntasan hasil belajar pada siklus 1 sebesar $45 \%$ atau 9 siswa.Sedangkan siklus 2 ketuntasan hasil belajar mencapai $75 \%$ atau 15 siswa.Dengan demikian indikator pencapaian mengalami peningkatan.

\section{DAFTAR PUSTAKA}

Arikunto, S. dkk. 2014. PenelitianTindakan Kelas. Jakarta : Bumi Aksara.

Arsyad, A. 2011. Media Pembelajaran. Jakarta: Raja Grafindo Persada.

Daryanto. 2010. Media Pembelajaran. Yogyakarta: Gava Media.

Djamarah S. 2010. Guru \& Anak Didik Dalam Interaksi Edukatif. Jakarta: PT Rineka Cipta.

Pratiwi. 2013. Meningkatkan keaktifan belajar siswa dalam pembelajaran IPS menggunakan media gambar, Jurnal skripsi,(http://eprints.uny.ac.id/ 15664/1/SKRIPSI\%20WINDA\%20E RWIN\%20PRATIWI_NIM.0910824 4003.pdf, diunduh 08 April 2016). 